\title{
Isolation and Characterization of a Vibrio Sp. Strain MA3 Possibly Associated with Mass Mortalities of the Pearl Oyster Pinctada fucata
}

Akihiro SAKATOKU ( $\nabla$ sakatoku@sci.u-toyama.ac.jp )

University of Toyama https://orcid.org/0000-0001-8333-1531

Kaito Hatano

University of Toyama

Shoki Tanaka

Mie university

Tadashi Isshiki

Mie University

\section{Short Report}

Keywords: Vibrio sp. strain MA3, Pinctada fucata, mass mortality, pathogenic bacteria, hemolysin

Posted Date: June 4th, 2021

DOI: https://doi.org/10.21203/rs.3.rs-515834/v1

License: (c) (i) This work is licensed under a Creative Commons Attribution 4.0 International License. Read Full License 


\section{Abstract}

In the summers of 2019 and 2020, a previously undescribed disease occurred in both juvenile and adult shellfish, causing mass mortalities in cultured pearl production, characterized by the major symptom of extreme atrophy of the soft tissues, including the mantle. However, the causative organism was uncertain. We isolated Vibrio sp. strain MA3 from the mantles of diseased pearl oysters Pinctada fucata. Analyses of 16S rRNA gene and DNA gyrase sequence homologies and its biochemical and morphological characteristics suggested that strain MA3 is a new strain of Vibrio alginolyticus. In addition, a hemolysin gene (Vhe1) of strain MA3 was detected as one of the virulence factors, and the complete sequence was determined. BLAST searches showed that Vhe1 shares $99.8 \%$ nucleotide sequence identity with Vibrio alginolyticus strain A056 lecithin-dependent hemolysin (Idh) gene, complete cds. Experimental infection of healthy oysters via injection with strain MA3 indicated it could cause high mortalities of the typically affected oysters from which the strain was isolated. These results suggest that the newly isolated Vibrio sp. strain MA3 is a putative causal agent of the recent disease outbreaks in Akoya pearl oysters.

\section{Introduction}

The cultured pearl industry was started by Mikimoto Kokichi in 1893 [Nagai 2013], and pearl production has become an important export industry in Japan. However, in the summers of 2019 and 2020, a previously undescribed disease occurred in not only juveniles but also in adult shellfish, causing mass mortalities. The disease was characterized by its major symptom: an extreme atrophy of the soft tissues, including the mantle. News reports stated that at least 2 million juvenile shellfish died in Mie Prefecture alone, resulting in a loss of more than 300 million yen. Although measures to prevent this disease were urgent, the cause was still unknown.

Various bacterial infections cause disease in cultured marine fish and shellfish, notably infections with Lactococcus garvieae (lactococcosis) [Meyburgh et al. 2017], Streptococcus dysgalactiae (streptococcosis) [Nomoto et al. 2004], Edwardsiella tarda (edwardsiellosis) [Mohanty and Sahoo 2007], and Tenacibaculum maritimum (tenacibaculosis) [Avendaño-Herrera et al. 2006]. In the Japanese mariculture industry, such diseases result in annual losses equivalent to more than 200 million U.S. dollars, including the cost for medications [Kusuda and Kawai 1998]. However, to the best of our knowledge, previous research has considered only two bacterial pathogens in pearl oysters: akoya oyster disease (AOD) from infection with a spirochete [Matsuyama et al. 2017], and black-spot shell disease from infection with Tenacibaculum sp. strain Pbs-1 [Sakatoku et al. 2018].

In this study, we describe the isolation and characterization of another pathogenic bacterium as a first step towards resolving the recent disease outbreaks in cultured pearl oysters, as characterized by extreme atrophy of their soft tissues. Furthermore, we reproduced the disease by experimentally infecting healthy oysters, via injection, with the isolated Vibrio sp. strain MA3.

\section{Materials And Methods}

\section{Isolation and characterization of the pathogenic bacterium}

Five diseased pearl oysters Pinctada fucata martensii (Akoya) (Fig. 1) and one healthy oyster (average body weight $50.2 \mathrm{~g}$ ) were collected from the pearl oyster farm in Ago Bay in Shima City, Mie Prefecture, Japan. After external and internal observations of the oysters, the mantle, gills, and adductor muscle were punctured with a platinum 
loop and streaked on $\mathrm{AO}$ agar plates ( $5 \%$ tryptone, $0.5 \%$ yeast extract, $0.2 \%$ beef extract, $0.2 \%$ sodium acetate, and $1.5 \%$ agar) with $70 \%$ seawater [Pazos et al. 1996], and the plates were incubated at $25^{\circ} \mathrm{C}$ for $48 \mathrm{~h}$. The dominant bacterial colonies on the plates were then spread on new AO agar medium and isolated. Finally, any bacterial clones were preserved on AO agar slants or plates for use in this study.

First, the morphology and motility of the isolated bacteria were observed by phase-contrast microscopy (Olympus BX51; Tokyo, Japan). Next, the samples were prepared for examination by negative staining with $1 \% \mathrm{w} / \mathrm{v}$ phosphotungstic acid and then observed under a JEM-100SX electron microscope (JEOL, Tokyo, Japan). Micrographs were taken at an accelerating voltage of $80 \mathrm{kV}$. Genomic DNA was extracted from a colony, and then 16S rRNA gene and DNA gyrase B $(g y r B)$ were amplified by polymerase chain reaction (PCR) using the following universal primers; 16S rRNA gene: 27f (AGAGTTTGATCCTGGCTCAG) and 1525r (5AAAGGAGGTGATCCAGCC), GyrB: UP-1 (GAAGTCATCATGACCGTTCTGCAYGCNGGNGGNAARTTY) and UP-2r (AGCAGGGTACGGATGTGCGAGCCRTCNACRTCNGCRTCNGTC) [Kang et al. 2009; Yamamoto and Harayama 1995]. The amplified products were purified using a QIAquick PCR Purification Kit (Qiagen K.K., Tokyo, Japan), followed by direct sequencing using a BigDye Terminator v3.1 Cycle Sequencing Kit (Applied Biosystems, Foster City, CA, USA) and an ABI Prism 3130xI Genetic Analyzer (Applied Biosystems). The following primers were used; 16S rRNA gene: r1L (GTATTACCGCGGCTGCTGG), r2L (CATCGTTTACGGCGTGGAC), r3L (TTGCGCTCGTTGCGGGACT), r4L (ACGGGCGGTGTGTACAAG), f1L (GAGTTTGATCCTGGCTCAG), f3L (GTCCCGCAACGAGCGCAAC), and 926f (AAACTCAAAGGAATTGACGG), GyrB: UP-1S (GAAGTCATCATGACCGTTCTGCA) and UP-2Sr (AGCAGGGTACGGATGTGCGAGCC). Sequence similarities between the isolates and the sequences available in public databases were then searched using the BLAST program on the National Center for Biotechnology Information (NCBI) website (http://www.ncbi.nlm.nih.gov). Gram-staining was performed using a FAVOR-G SET-S kit (Nissui Pharmaceutical Co. Ltd., Tokyo, Japan). Biochemical characterization was performed using API 20E and API ZYM tests (bioMérieux, Marcy- I'Etoile, France). Growth at $5-55^{\circ} \mathrm{C}$ on AO medium was measured for 2 days to determine the optimal temperature and temperature range for growth. Growth at various concentrations of seawater $(0-90 \% \mathrm{v} / \mathrm{v})$ was investigated for 3 days by supplementing the medium with appropriate concentrations of seawater. The effect of antibiotics on cell growth was assessed after 2 days of incubation at $25^{\circ} \mathrm{C}, \mathrm{using} \mathrm{BD}$ BBL Sensi-Disc Antimicrobial Susceptibility Test Discs (Becton, Dickinson and Company, Franklin Lakes, New Jersey, USA) on AO agar plates.

\section{Isolation of hemolysin gene}

The partial hemolysin gene fragment was PCR-amplified using the primer pair thF (TCTAGCGAACGAGAACGCAG) and thR (ACTGCCCAGTTGTATAGCGG), designed on the basis of Vibrio alginolyticus hemolysin [Lv et al. 2019]. The amplification products were purified and sequenced following the same method as gyr $B$ gene sequencing. The full lengths of the hemolysin gene were sequenced by the primer walking [Szybalski 1993] and inverse PCR [Howard et al. 1988] methods. Restriction digests were performed using $3 \mu \mathrm{g}$ of genomic DNA treated with $40 \mathrm{U}$ of BamHI. One nanogram of digested DNA was then circularized with a Rapid DNA Dephos \& Ligation Kit (Roche, Manheim, Germany). The ligated sample was treated with an equal volume of phenol-chloroform-isoamyl alcohol mixture (25:24:1) before the aqueous phase was recovered. The DNA was precipitated with ethanol and collected by centrifugation. The entire genes were amplified by nested PCR. The two sets of primers used were designed from the partially sequenced hemolysin gene. Primer sequences were as follows: 1st-f, TCTTTAACGCGTCCCAATGG; 1st-r, CTATCGCCTAAAGCCACTAC; 2nd-f, CTAACCCGAATAGCTGGTTC; 2nd-r, GATCTGGTTGCATTGCAGCA. The first amplification reaction was performed in a $40-\mu \mathrm{l}$ PCR reaction mixture 
containing 1 × PCR buffer for KOD FX (Toyobo, Osaka, Japan), $0.3 \mu \mathrm{mol} \mathrm{I}^{-1}$ of each primer, $0.4 \mathrm{mmol} \mathrm{I}^{-1}$ of dNTPs, 1 $\mathrm{U}$ of KOD FX (Toyobo), and $1 \mathrm{ng}$ of precipitated DNA. The PCR amplification was performed using an initial denaturation step of $94^{\circ} \mathrm{C}$ for $2 \mathrm{~min}$, followed by 30 cycles at $98^{\circ} \mathrm{C}$ for $10 \mathrm{sec}, 50{ }^{\circ} \mathrm{C}$ for $30 \mathrm{sec}$, and $68^{\circ} \mathrm{C}$ for $4 \mathrm{~min}$, before the temperature was maintained at $4^{\circ} \mathrm{C}$. In the second PCR, $1 \mu \mathrm{l}$ of the amplified product of the first PCR was used as a template, and the reaction cycle was carried out under the same conditions. The resulting PCR products were also purified and sequenced as described for the gyrB gene. Nucleotide and deduced amino acid sequence analyses, open reading frame (ORF) searches, and molecular-mass and isoelectric-point calculations were performed using Genetyx Ver.8 software (Genetyx Corporation, Tokyo, Japan). A database homology search was performed using the BLAST program on the NCBI website.

\section{Experimental infection of pearl oysters with the isolated bacterium}

For the infection-challenge experiment, apparently healthy pearl oysters (average body weight $47.6 \mathrm{~g}$ ), in which the present disease was not detected, were obtained from a private hatchery in Mie Prefecture. Oysters were allowed to adapt in artificial seawater for 19 days at $25^{\circ} \mathrm{C}$ or 6 days at $28^{\circ} \mathrm{C}$. Prior to use, 10 oysters were randomly selected and bacteriologically tested to confirm the absence of Vibrio species. The bacterial strain originally isolated from a diseased pearl oyster in Ago Bay, Mie Prefecture, was selected as the representative strain. The bacteria were grown in $\mathrm{AO}$ medium at $25^{\circ} \mathrm{C}$ for $24 \mathrm{~h}$ with shaking. After sterilization of the shell surface with $70 \%$ ethanol, these oysters were then divided into two test groups and two control groups ( $n=10$ each group). In the test groups, the adductor muscle of the oysters was injected with $100 \mu \mathrm{l}$ of the bacterial suspension $\left(1.2 \times 10^{8}\right.$ or $1.7 \times 10^{8}$ CFU/oyster) in AO medium. The control groups were treated similarly but with sterile AO medium instead of bacterial suspension. After the infection challenge, the oysters in each group $(n=10)$ were maintained individually in 3-I polyethylene beakers containing artificial seawater, at $25^{\circ} \mathrm{C}$ for 30 days or at $28{ }^{\circ} \mathrm{C}$ for 14 days, without feeding. The water was partially changed (50\%) twice weekly. Each group was monitored daily for mortalities over the experimental period. We collected the dead individuals during the experiment and the surviving individuals at the end of the experiment, and isolated the bacteria from the gills, mantle, and adductor muscles of individuals following a described above procedure of bacterial examination of naturally diseased oysters. Slide agglutination tests with rabbit anti-MA3 serum were conducted to identify the isolates.

\section{Nucleotide sequence accession number}

The GenBank/EMBL/DDBJ accession numbers of the nucleotide sequence of the 16S rRNA gene, gyrB gene and hemolysin gene (Vhe1) of strain MA3 reported in this paper are LC628646, LC619648 and LC619649, respectively.

\section{Results And Discussion}

Diseases caused by pathogenic bacteria, including Edwardsiella tarda [Nakatsugawa 1893], Lactococcus garvieae [Meyburgh et al. 2017], Pseudomonas plecoglossicida [Zhang et al. 2014], Streptococcus iniae[Agnew and Barnes 2007], and Vibrio alginolyticus [Rameshkumar et al. 2017], have been reported in various cultured fish and shellfish. During periods of high seawater temperatures (summer) in Japan in 2019 and 2020, a serious disease outbreak occurred in Akoya pearl oyster Pinctada fucata farms, causing mass mortalities. The diseased oysters exhibited extremely atrophied soft tissues, including the mantle and gills, accompanied by blackish discoloration in part. We considered that this disease was caused by a bacterial infection and thus tried to isolate the causative organism from diseased oysters. Bacteria forming similar white colonies were isolated from the mantle, gills, and adductor 
muscles of all diseased oysters, but not from any of the healthy oysters. We characterized one of the isolated bacterial strains (MA3) in detail.

Strain MA3 is a motile gram-negative bacterium with an average $1.5-\mu \mathrm{m}$ wide and $3.0-\mu \mathrm{m}$ long, and has a single lateral flagellum (Fig. 2). The 1489-bp 16S rRNA gene and 1197-bp gyrB gene sequence of strain MA3 were used to identify the strain to species. The sequences showed $99.9 \%$ similarity with Vibrio alginolyticus strain NBRC 15630 (GenBank accession number NR_121709) and 99.6\% similarity with Vibrio alginolyticus strain VABZ0005 (GenBank accession number JQ698511), respectively. We designated the isolate as Vibrio sp. strain MA3. The 16S rRNA gene and gyrB gene sequences of MA3 were deposited in GenBank under accession no. LC628646 and LC619648, respectively.

Bacteria of genus Vibrio are abundant in marine waters [Thompson et al. 2004]. The Harveyi clade is also known as the Vibrio core group [Sawabe et al. 2007]. This clade includes the following species: $V$. harveyi, V. campbellii, $V$. rotiferianus, V. parahaemolyticus, V. alginolyticus, V. natriegens, and V. mytili [Sawabe et al. 2007]. To our knowledge, this is the first report to isolate a species of Vibrio of the Harveyi clade from Pinctada fucata. Clam production is often affected by vibriosis, which leads to high mortality rates mainly in nursery cultures of juvenile bivalves [Castro et al. 1992; Gómez-León et al. 2005; Nicolas et al. 1992; Richards et al. 2015]. Our results suggest that infection with Vibrio sp. MA3 was associated with the observed disease in which the mantle of pearl oysters became extremely atrophied.

Strain MA3 could grow at $10-45^{\circ} \mathrm{C}$ (with optimal growth occurring at $25-45^{\circ} \mathrm{C}$ ) and $10-90 \%(w / v)$ seawater. These results suggest that strain MA3 can survive in brackish water in winter. Strain MA3 was identified as a closely related species of $V$. alginolyticus. However, strain MA3 showed some important differences from the typestrain of $V$. alginolyticus ATCC 17749. Table 1 lists the differential phenotypic characteristics of $V$. alginolyticus ATCC $® 17749^{\text {TM }}$ [Abdallah et al. 2009; Ghosh and Bhadury 2019; Hörmansdorfer et al. 2000]. MA3 was negative for tryptophane deaminase and acetoin production in the API 20E system (Table 1). MA3 was positive for lipase (C14), valine arylamidase and a-glucosidase, and it was negative for a-chymotrypsin in the API ZYM system (Table 1). Strain MA3 was susceptible to chloramphenicol but resistant to kanamycin, vancomycin, tetracycline, ampicillin, penicillin and streptomycin (Table 1). These results suggest that MA3 is a new strain of Vibrio alginolyticus. In the future, a more detailed characterization (the full genome, ANI analysis or MALDI-TOF analysis) will be needed.

The full-length hemolysin gene from Vibrio sp. MA3 (GenBank accession no. LC619649) was obtained by inverse PCR. The obtained gene was 2063-bp containing a 1254-bp ORF that was designated Vhe1. (Fig. 3). The deduced product of the Vhe1 gene is a protein of 417 amino acids, which has an estimated molecular mass of $47.2 \mathrm{kDa}$ and a pl of 5.01 (Fig. 3). This protein has a typical signal peptide with a cleavage site between Ala19 and Glu20 at the $\mathrm{N}$-terminal end of the protein sequence. A BLAST homology search of the GenBank database showed that Vhe1 shares $99.8 \%$ nucleotide sequence identity with Vibrio alginolyticus strain A056 lecithin-dependent hemolysin (Idh) gene, complete cds (JX064518). The similarity levels of the deduced amino acid sequence were $100 \%$ with thermolabile hemolysin [Vibrio alginolyticus NBRC 15630 = ATCC 17749] (accession no. AGV19473). In general, bacterial hemolysins have been suggested to be important factors of pathogenic vibrios by causing hemorrhagic septicemia in the host [Zhang et al. 2001]. Hemolysin produced by pathogens can lyse host cells and release ironcontaining compounds such as heme or hemoglobin that are beneficial for bacterial growth in the host [Stoebner and Payne 1988]. Because the strain MA3 possessed hemolysin gene, the possibility of causing vibriosis by infecting pearl oyster was considered. In the future, this hemolysin must be purified and characterized in detail. 
The results of the experimental infection are summarized in Table 2. Mortality occurred only in the test group at $28^{\circ} \mathrm{C}$, but not in the other test group at $25^{\circ} \mathrm{C}$, nor in the control groups at both $25^{\circ} \mathrm{C}$ and $28^{\circ} \mathrm{C}$. The first dead individual in the test group at $28^{\circ} \mathrm{C}$ appeared 1 day after injection, after which the mortality rate increased dramatically, resulting in $90 \%$ at the end of the experimental period. The dead oysters usually exhibited the same symptoms as described above for naturally diseased oysters. Strain MA3 was isolated from the mantle, gill or adductor muscle tissue of all dead individuals in the test group at $28^{\circ} \mathrm{C}$, with a high isolation rate of $88.9-100 \%$ for each tissue. We could not isolate strain MA3 from any surviving individuals in either the test groups or control groups. These results allowed us to infer that the present disease could be reproduced in healthy oysters by experimentally injecting strain MA3.

Note that the lethality of strain MA3 was found only at $28^{\circ} \mathrm{C}$, but not at $25^{\circ} \mathrm{C}$, although the strain grew optimally at both temperatures, as described above in its characterization. Therefore, the susceptibility of oysters to strain MA3 might depend on water temperature. This is supported by a previous report [Numaguchi 1994] in which the filtration rate of Akoya pearl oysters increased with increasing water temperatures up to $25-28^{\circ} \mathrm{C}$, whereas their filtration rate was very low at $31^{\circ} \mathrm{C}$. Furthermore, the rate diminished remarkably in summer at water temperatures above $28^{\circ} \mathrm{C}$. Considering the physiological evidence, we speculate that the susceptibility of oysters to strain MA3 increases with increasing water temperatures from $25^{\circ} \mathrm{C}$ to $28^{\circ} \mathrm{C}$, by possibly affecting the organism's physiological functions, such as its defense mechanisms against the pathogenic bacteria. Hence, it is probable that the higher temperatures in summer play an important role in affecting such defense mechanisms in cultured oysters.

\section{Conclusion}

We isolated a Vibrio sp. strain MA3 from the mantle and other soft tissues of diseased pearl oysters. Strain MA3 possessed a pathogenic factor, hemolysin (Vhe1), of vibriosis. Moreover, the results of the infection-challenge experiment in this study provide evidence that strain MA3 was one of the putative causal agents of mass mortalities of farmed pearl oysters in Japan in the summers of 2019 and 2020.

\section{Declarations}

\section{Acknowledgements}

This work was supported by JSPS KAKENHI (grant number 20K06203); Grants-in-Aid for Exploratory Research, the Kurita Water and Environment Foundation (KWEF) (grant number 20E003); and the cooperative research program of the Institute of Nature and Environmental Technology, Kanazawa University (grant number 20034). Cynthia Kulongowski (MSc), with the Edanz Group (https://en-author-services.edanz.com/ac), edited a draft of this manuscript.

\section{Author Contributions}

AS and $\mathrm{KH}$ performed the characterization of Vibrio sp. strain MA3. ST and TI performed experimental infection of pearl oysters. AS and TI wrote the manuscript and conceived the overall study.

\section{Conflict of interest}

The authors declare that the research was conducted in the absence of any commercial or financial relationships that could be construed as a potential conflict of interest. 


\section{References}

1. Abdallah FB, Kallel H, Bakhrouf A (2009) Enzymatic, outer membrane proteins and plasmid alterations of starved Vibrio parahaemolyticus and Vibrio alginolyticus cells in seawater. Arch Microbiol 191: 493-500.

2. Agnew W, Barnes AC (2007) Streptococcus iniae: an aquatic pathogen of global veterinary significance and a challenging candidate for reliable vaccination. Vet Microbio/122: 1-15.

3. Avendaño-Herrera R, Toranzo AE, Magariños B (2006) Tenacibaculosis infection in marine fish caused by Tenacibaculum maritimum: a review. Dis Aquat Org71: 255-266.

4. Castro D, Martinez-Manzanares E, Luque A, Fouz B, Moriñigo MA, Borrego JJ, Toranzo AE (1992) Characterization of strains related to brown ring disease outbreaks in southwestern Spain. Dis Aquat Org14: 229-236.

5. Ghosh A, Bhadury P (2019) Vibrio chemaguriensis sp. nov., from Sundarbans, Bay of Bengal. Curr Microbio/76: 1118-1127.

6. Gómez-León J, Villamil L, Lemos ML, Novoa B, Figueras A (2005) Isolation of Vibrio alginolyticus and Vibrio splendidus from aquacultured carpet shell clam (Ruditapes decussatus) larvae associated with mass mortalities. App/ Environ Microbio/71: 98-104.

7. Hörmansdorfer S, Wentges H, Neugebaur-Büchler K, Bauer J (2000) Isolation of Vibrio alginolyticus from seawater aquaria. Int J Hyg Environ Health203: 169-175.

8. Howard O, Gerber AS, Hartl DL (1988) Genetic applications of an inverse polymerase chain reaction. Genetics120: 621-623.

9. Kang Y, Takeda K, Yazawa K, Mikami Y (2009) Phylogenetic studies of Gordonia species based on gyrB and secA1 gene analyses. Mycopathologia167: 95-105.

10. Kusuda R, Kawai K (1998) Bacterial diseases of cultured marine fish in Japan. Fish Patho/33: 221-227.

11. Lv T, Song T, Liu H, Peng R, Jiang X, Zhang W, Han Q (2019) Isolation and characterization of a virulence related Vibrio alginolyticus strain Wz11 pathogenic to cuttlefish, Sepia pharaonis. Microb Pathog126: 165-171.

12. Matsuyama T, Yasuike M, Fujiwara A, Nakamura Y, Takano T, Takeuchi T, Satoh N, Adachi Y, Tsuchihashi Y, Aoki H, Odawara K, Iwanaga S, Kurita J, Kamaishi T, Nakayasu C (2017) A Spirochaete is suggested as the causative agent of Akoya oyster disease by metagenomic analysis. PLoS One12: e0182280. doi:

10.1371/journal.pone.0182280.

13. Meyburgh CM, Bragg RR, Boucher CE (2017) Lactococcus garvieae: an emerging bacterial pathogen of fish. Dis Aquat Org123: 67-79.

14. Mohanty BR, Sahoo PK (2007) Edwardsiellosis in fish: a brief review. J Biosci32: 1331-1344.

15. Nagai K (2013) A history of the cultured pearl industry. Zoo Sci30: 783-793.

16. Nakatsugawa T (1893) Edwardsiella tarda isolated from cultured young flounder. Fish Patho/18: 99-101.

17. Nicolas JL, Ansquer D, Cochard JC (1992) Isolation and characterization of a pathogenic bacterium specific to Manila clam Tapes philippinarum larvae. Dis aquat Org14: 153-159.

18. Nomoto R, Munasinghe LI, Jin DH, Shimahara Y, Yasuda H, Nakamura A, Misawa N, Itami T, Yoshida T (2004) Lancefield group C Streptococcus dysgalactiae infection responsible for fish mortalities in Japan. J Fish Dis27: 679-686.

19. Numaguchi K (1994) Effect of water temperature on the filtration rate of Japanese pearl oyster, Pinctada fucata martensii. Aquacult Sci42: 1-6. 
20. Pazos F, Santos Y, Macías AR, Núñez S, Toranzo AE (1996) Evaluation of media for the successful culture of Flexibacter maritimus. J Fish Dis19: 193-197.

21. Rameshkumar P, Nazar AKA, Pradeep MA, Kalidas C, Jayakumar R, Tamilmani G, Sakthivel M, Samal AK, Sirajudeen S, Venkatesan V, Nazeera BM (2017) Isolation and characterization of pathogenic Vibrio alginolyticus from sea cage cultured cobia (Rachycentron canadum (Linnaeus 1766)) in India. Lett Appl Microbiol 65: 423-430.

22. Richards GP, Watson MA, Needleman DS, Church KM, Häse CC (2015) Mortalities of Eastern and Pacific oyster Larvae caused by the pathogens Vibrio coralliilyticus and Vibrio tubiashii. Appl Environ Microbio/81: 292-297.

23. Sakatoku A, Fujimura T, Ito M, Takashima S, Isshiki T (2018) Newly isolated bacterium Tenacibaculum sp. strain Pbs-1 from diseased pearl oysters is associated with black-spot shell disease. Aquaculture493: 61-67.

24. Sawabe T, Kita-Tsukamoto K, Thompson FL (2007) Inferring the evolutionary history of vibrios by means of multilocus sequence analysis. J Bacterio/189: 7932-7936.

25. Stoebner JA, Payne SM (1988) Iron-regulated hemolysin production and utilization of heme and hemoglobin by Vibrio cholerae. Infect Immun56: 2891-2895.

26. Szybalski W (1993) From the double-helix to novel approaches to the sequencing of large genomes. Gene15: 279-290.

27. Thompson FL, lida T, Swings J (2004) Biodiversity of vibrios. Microbiol Mol Biol Rev68: 403-431.

28. Yamamoto S, Harayama S (1995) PCR amplification and direct sequencing of gyrB genes with universal primers and their application to the detection and taxonomic analysis of pseudomonas putida strains. App/ Environ Microbio/61: 1104-1109.

29. Zhang XH, Meaden PG, Austin B (2001) Duplication of Hemolysin Genes in a Virulent Isolate of Vibrio harveyi. Appl Environ Microbio/67: 3161-3167.

30. Zhang JT, Zhou SM, An SW, Chen L, Wang GL (2014) Visceral granulomas in farmed large yellow croaker, Larimichthys crocea (Richardson), caused by a bacterial pathogen, Pseudomonas plecoglossicida. J Fish Dis37: 113-121.

\section{Tables}

Table 1 Differential characteristics of strain MA3 and V. alginolyticus ATCC 17749 


\begin{tabular}{|c|c|c|}
\hline Characteristic & Vibrio sp. MA3 & V. alginolyticus ATCC $17749^{1,2,3}$ \\
\hline \multicolumn{3}{|l|}{ API 20E } \\
\hline \multicolumn{3}{|l|}{ Reactions/Enzymes } \\
\hline ß-galactosidase & - & - \\
\hline Arginine dihydrolase & - & - \\
\hline Lysine decarboxylase & + & + \\
\hline Ornithine decarboxylase & - & - \\
\hline Citrate utilization & - & - \\
\hline $\mathrm{H}_{2} \mathrm{~S}$ production & - & - \\
\hline Urease & - & - \\
\hline Tryptophane deaminase & - & ND \\
\hline Indole production & + & + \\
\hline Acetoin production & - & - \\
\hline Gelatinase & + & + \\
\hline \multicolumn{3}{|l|}{ Fermentation/Oxidation } \\
\hline D-glucose & + & + \\
\hline D-mannitol & + & + \\
\hline inositol & + & + \\
\hline D-sorbitol & - & - \\
\hline L-rhamnose & - & - \\
\hline D-sucrose & + & + \\
\hline D-melibiose & - & - \\
\hline Amygdalin & - & + \\
\hline L-arabinose & - & - \\
\hline \multicolumn{3}{|l|}{ API ZYM } \\
\hline Alkaline phosphatase & + & + \\
\hline Esterase (C4) & + & + \\
\hline Esterase Lipase (C8) & + & + \\
\hline Lipase (C14) & + & - \\
\hline Leucine arylamidase & + & + \\
\hline Valine arylamidase & + & - \\
\hline
\end{tabular}




\begin{tabular}{|c|c|c|}
\hline Cystine arylamidase & - & - \\
\hline Trypsin & + & + \\
\hline a-chymotrypsin & - & + \\
\hline Acid phosphatase & + & + \\
\hline Naphtol-AS-BI-phosphohydrolase & - & - \\
\hline a-galactosidase & - & - \\
\hline$\beta$-galactosidase & - & - \\
\hline$\beta$-glucuronidase & - & - \\
\hline a-glucosidase & + & - \\
\hline$\beta$-glucosidase & - & - \\
\hline N-acetyl- $\beta$-glucosaminidase & - & - \\
\hline a-mannosidase & - & - \\
\hline a-fucisidase & - & - \\
\hline \multicolumn{3}{|l|}{ Antibiotics } \\
\hline Kanamycin & $\mathrm{R}$ & S \\
\hline Gentamycin & $\mathrm{R}$ & S \\
\hline Tetracycline & $\mathrm{R}$ & S \\
\hline Ampicillin & $\mathrm{R}$ & $\mathrm{R}$ \\
\hline Penicillin & $\mathrm{R}$ & $\mathrm{R}$ \\
\hline Vancomycin & $\mathrm{R}$ & ND \\
\hline Chloramphenicol & $S$ & $S$ \\
\hline Streptomycin & $\mathrm{R}$ & $\mathrm{S}$ \\
\hline
\end{tabular}

+: Positive, -: Negative, R: Resistance, S: Sensitive, ND: No data

${ }^{1}$ Ghosh and Bhadury (2019) Curr Microbiol 76: 1118-1127.

2 Abdallah et al. (2009) Arch Microbiol 191: 493-500.

${ }^{3}$ Hörmansdorfer et al. (2000) Int J Hyg Environ Health 203: 169-175.

Table 2 Results of experimental infection of pearl oysters Pinctada fucata with Vibrio sp. strain MA3 following its injection into the adductor muscle 


\begin{tabular}{|c|c|c|c|c|c|c|c|c|c|}
\hline \multirow{3}{*}{$\begin{array}{l}\text { Water } \\
\text { temperature } \\
\left({ }^{\circ} \mathrm{C}\right)\end{array}$} & \multirow{3}{*}{$\begin{array}{l}\text { Rearing } \\
\text { period } \\
\text { (days) }\end{array}$} & \multirow[t]{3}{*}{ Group } & \multirow{3}{*}{$\begin{array}{l}\text { Mortality } \\
(\%)^{1}\end{array}$} & \multicolumn{6}{|c|}{ Isolation rate of the strain MA3 (\%) ${ }^{2}$} \\
\hline & & & & \multicolumn{3}{|c|}{ Dead individual } & \multicolumn{3}{|c|}{ Surviving individual } \\
\hline & & & & Adductor & Mantle & Gill & Adductor & Mantle & Gill \\
\hline \multirow[t]{2}{*}{25} & 30 & Test & $0(0 / 10)$ & ND & ND & ND & $0(0 / 10)$ & $\begin{array}{l}0 \\
(0 / 10)\end{array}$ & $\begin{array}{l}0 \\
(0 / 10)\end{array}$ \\
\hline & & Control & $0(0 / 10)$ & ND & ND & ND & $0(0 / 10)$ & $\begin{array}{l}0 \\
(0 / 10)\end{array}$ & $\begin{array}{l}0 \\
(0 / 10)\end{array}$ \\
\hline \multirow[t]{2}{*}{28} & 14 & Test & $\begin{array}{l}90.0 \\
(9 / 10)\end{array}$ & $\begin{array}{l}88.9 \\
(8 / 9)\end{array}$ & $\begin{array}{l}100.0 \\
(9 / 9)\end{array}$ & $\begin{array}{l}100.0 \\
(6 / 6)^{3}\end{array}$ & $0(0 / 1)$ & $0(0 / 1)$ & $\begin{array}{l}0 \\
(0 / 1)\end{array}$ \\
\hline & & Control & $0(0 / 10)$ & ND & ND & ND & $0(0 / 10)$ & $\begin{array}{l}0 \\
(0 / 10)\end{array}$ & $\begin{array}{l}0 \\
(0 / 10)\end{array}$ \\
\hline
\end{tabular}

${ }^{1}$ Numbers in parentheses indicate the number of dead individuals/number of experimental individuals.

${ }^{2}$ Numbers in parentheses indicate the number of positive samples/number of samples examined.

${ }^{3}$ The gills from three individual oysters could not be examined because of autolysis of the gills after death.

ND: No data.

\section{Figures}

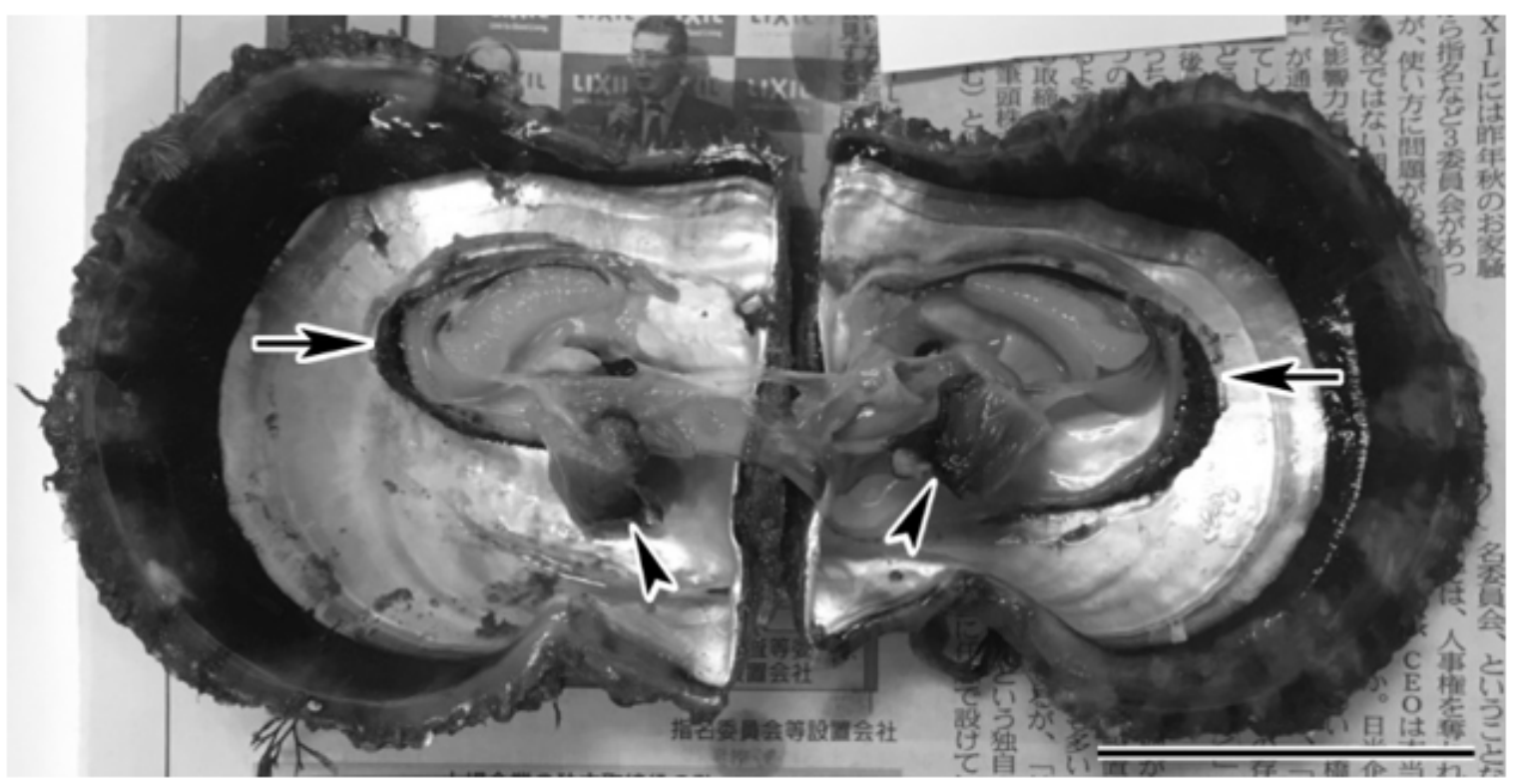

\section{Figure 1}

Photograph of a diseased pearl oyster Pinctada fucata, showing extreme atrophy of the soft tissues, including the mantle (arrows) and gills (arrow heads), accompanied by blackish discoloration in part. The scale bar indicates 5 $\mathrm{cm}$ 


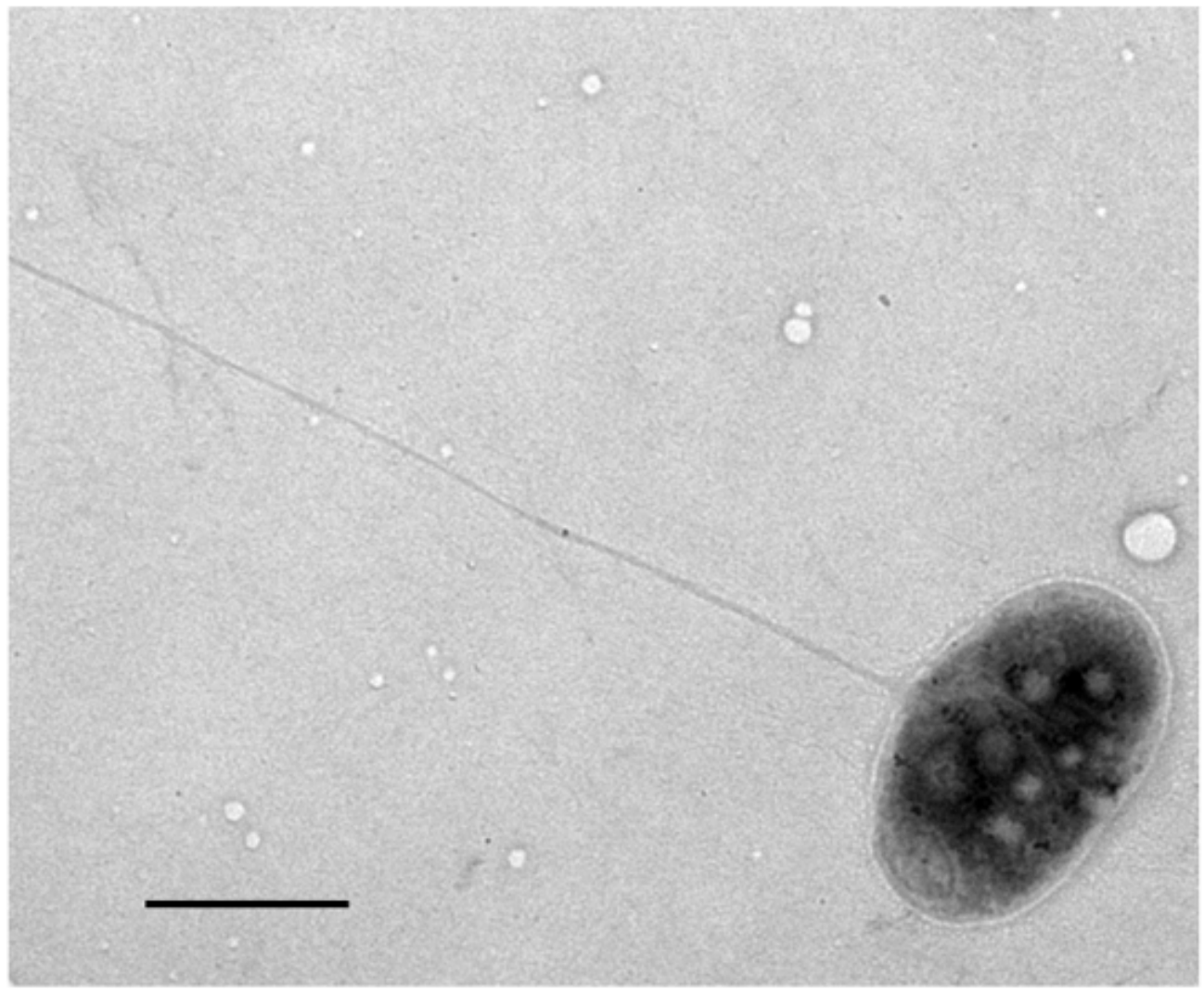

\section{Figure 2}

Electron micrograph of a negatively stained MA3 cell, revealing its rod shape and single lateral flagellum. The scale bar indicates $1 \mu \mathrm{m}$ 


\section{Figure 3}

Nucleotide sequences and deduced amino acid sequences of the gene (Vhe1) encoding a hemolysin. Start and stop codons are shown in bold; the predicted signal peptide is boxed 